\title{
Assessing the Teaching/Learning Programs and the Professionalization of Higher Education in the University of Maroua, Far North Region of Cameroon
}

\author{
Dr Asongwe Cyprian Foche* \\ Department of Sciences of Education University of Maroua BP 55 Maroua, Cameroon
}

*Corresponding Author: Dr Asongwe Cyprian Foche, Department of Sciences of Education University of Maroua BP 55 Maroua, Cameroon

\begin{abstract}
This paper probes in to the problem of professionalization by assessing the impact of the teaching/learning programs on the professionalization of higher education in the University of Maroua, with emphasis on the integration of theory and practice in the programs of learning, qualification and competence of teachers, dissemination of information on the competences of each degree program and the learning infrastructure. The study is built on a survey design with a sample of three hundred and thirteen students of the University. A questionnaire was constructed on a five modality Likert Scale. The data was analyzed with SPSS 20.0, using multivariate regression analysis model. Findings reveals limited professionalization in the teaching/learning programs, teachers' qualification and competence averagely reflects professionalization, while learning infrastructure insufficiently supports professionalization. The study strongly recommends a higher education curricula that is relevant to the socio-economic needs of the nation, which will provide a balanced curricula that is responsive, culturally sensitive and adequately supported by appropriate teaching and learning materials. Finally, university-industry interaction should be enhance through internship placements of students and signing of conventions and corporation accords.
\end{abstract}

Keywords: Teaching/Learning, Professionalization, Higher education, Competences, Theory and Practice.

\section{INTRODUCTION}

Higher education (HE) plays an important role in the development of most nations. Developing nations have been working to uplift their standards since the last two decades by initiating a series of institutional reforms in Universities, as is the case in Cameroon with the 2007 Bachelor-MastersDoctorate (BMD) and the 2008 New University Governance Program on the professionalization of Higher Education in the country. The main driving force for change is increased demand for more professionalization of Higher Education programs to suit the exigencies of the job market, more accountability and responsiveness to the needs and expectations of internal and external stakeholders who affect or are affected by the existence and functioning of universities. As pointed out by (Burrows, 1999), universities are increasingly challenged to be more responsible and accountable in the utilization of resources, provision of quality education and adherence to practices of value for money.

As institutions of Higher Education have become increasingly complex, issues of governance and professionalization have become a point of major concern (Gerber, 2001, Simplicio, 2006). This has been exacerbated by the increasing pressures and expectations being placed on higher educational institutions by governments' to render their training programs more adaptable to the needs of the job market. In Cameroon, the 1993 University Reforms, the Bologna Process, the 2001 Orientation Law on Higher Education, the 2007 Bachelor-Masters-Doctorate (BMD) Higher Education reforms and the 2008 New University Governance Program amongst other things have restructured governance and professionalization in the country's Higher Education system. There is a lot of evidence on the correlation between a country's quality of Higher Education system and its productive innovation, (Bloom, 2006). This would mean that the quality of Higher Education in a country could be reflected from the products of such a system. This paper not only focuses on the professionalization of university education, but how effective it is in the training programs in the University of Maroua. 
The triad mission of the University in Cameroon deals with Teaching, Research and Community Outreach. Events and changes of the contemporary global scene and technological advancements have compelled the modern university to be involved in the socio-economic development of most nations. This therefore explains why the Cameroon government since 1993 following the University Reforms has been making efforts through various reform policies to inculcate the New University Governance Program towards the professionalization of the higher education system in Cameroon. However, the changes involve in this transition can be achieve through a democratic process. The Adoption of the BMD Reform of 2007 in the CEMAC Zone and the New University Governance Program of 2008 are in response to the new exigencies of aligning our universities with professionalization and socioeconomic development.

\section{LITERATURE REVIEW}

Higher education especially university education focuses more on mono-disciplinarity and traditional learning (Dill, 2000). However, the dominant perspective is that universities are experiencing fundamental curriculum changes as a result of the new socio political and economic environment. The advent of information and communication technology (ICT) has transformed the economy from a production line work place to one in which innovation has become the key competitive advantage. This is dependent on increased levels of skills and knowledge to compete in the economic terrain and on using technology to innovate. This has placed demands on higher education to produce more graduates as well as graduates with high level skills to serve the economy.

The new paradigm of economic growth, focuses on the relationship between "knowledge" and economic development as express in the 2010 Sectorial Policy Document on higher education in Cameroon. According to policy makers, "economic growth and sustainable development in any modern economy depends heavily on the quality of higher education and scientific research". As a consequence, these changes to the new paradigms of economic growth not only implicate higher education but call for new roles, expectations and orientations where in any modern society higher education institutions come to be seen as "facilitators of innovations; product innovations, process innovations, social innovations, organizational innovations and training and certification innovations' (SPD, 2010). Thus the university should be in the business of understanding what it entails to render its disciplines professional and relevant to the world of work. This therefore suggests that one of the strategies through higher education is the necessity for the universities to align their programs and activities to the national development plans as the poverty reduction strategy paper (PRSP).

The university's role in the current socio-economic vision of Cameroon is about moving further from its traditional position to being able to participate in the development of industries, enterprises and innovations. While this assertion remains a subject of research and debate, it is however clear that the slow growth rate witnessed and the inability of our country to be globally and economically competitive means that the Cameroonian educational system, especially higher education needs to go further. The university is not supposed to evolve in parallel lines with socio-economic and productive actors and structures but in consonance with their activities. The activities of the universities have to be beneficial to industries and enterprises so as to be integrated into national research and development agenda. There is renewed emphasis on the links between higher education and the markets, (Marginson\& Van Der Wende (2007), by a scheme of "entrepreneurial universities" (Clark, 1998), and by notions of excellence and the centrality of managerial concepts and goals such as productivity and efficiency.

The rise in the number of unemployed graduates combined with limited professionalism of higher education in the country has raised questions on its usefulness and relevance. Despite the rise in student enrollment into institutions of higher education in Cameroon since independence (1960s) and rising number of graduates from the Universities, the employment of these graduates has been a serious problem. The curriculum designed in 1960s was severely inadequate for private sector demands during the 1990s. This coupled with the inability of the government to absorb graduates into the public service has degenerated the problem of unemployment. This is explained by the fact that the skills acquired from higher education were grossly inadequate for the requirements of the labor market leading to de-motivation of those aspiring to pursue studies at higher levels. 
Assessing the Teaching/Learning Programs and the Professionalization of Higher Education in the University of Maroua, Far North Region of Cameroon

University curriculum across the globe is experiencing significant pressure to transform from its 'insular', distant and abstract form to one that is more responsive to the direct needs of the society. This increased focus on responsiveness result in a shift towards mode to knowledge approaches (Gibbons, Limoges, Nowotny, Schwartzman, Scott and Trow, 1994) which prioritize curricula that focus on skills, application and problem solving. Given the important role higher education plays in the training and equipping of young graduates with professional skills and competences to better adapt to the exigencies of the employment market, this paper probes into the elements of professionalization in the University of Maroua such as the implementation of professionalization policies on teaching/learning programs, integration of theory and practice in training, teaching personnel and learning infrastructure

The lack of concrete professionalization in our Higher Education, unemployment of graduates cause all actors to rethink strategies of rendering our teaching/learning programs more adaptable through the acquisition of skills and competences to match the demands of the employment market, thereby attempting to provide a more sustainable solution to the problem of graduate employability. Findings obtained from the National Institute for Statistics in 2010 showed that unemployment in Cameroon was between 13 and $15.5 \%$. Underemployment was between 54.4 and $71.9 \%$ for the urban areas and $79.2 \%$ for rural areas. According to the Growth and Employment Strategy Paper of 2012 unemployment rates are very high standing at $88.8 \%$, meaning underemployment stands at 75.8 and unemployment at 13\%. In 2020, the latest value of unemployment in Cameroon stood at 3.43 percent. There is need for a good Higher Education curriculum that equips graduates with skills that can lead to decent employment in both the formal and informal sectors as well as self-employment opportunities.

Nowadays, parents and students display a strong preference for higher education that makes young people employable. Therefore, the availability and popularity of courses are being shaped by market forces. Universities are now introducing new courses for which there is a demand in the market. It can also be added that market forces are beginning to influence the research agenda of universities. According to (Machin\& McNally,2007), the expansion in higher education has predicted on the assumption that more education is good for individuals and for society as a whole, not only in economic outcomes such as wages or employment but also for social outcomes like improved health, reduced crime and higher well-being. However, as said earlier, along with this expansion of the system has come a range of issues related to the 'over-supply' of graduates, 'over-qualification' and skill mismatch or whether students are studying the 'right type' of subjects.

In the last decades, the wage premium attached to higher education has increased in most countries. In terms of employability, graduates tend to have a much higher probability of being in a job (Machin $\&$ McNally, 2007). According to (Nayyar, 2008), the world of professional education is been influence by globalization market, for example, engineering, management, medicine and law. Since professions are increasingly internationalized; globalization is also encouraging the harmonization of academic programs. Market forces and technical progress have opened a new world of opportunities for those enrolled in distance education. However, distance may not be affordable for some students especially in developing countries.

\section{RESEARCH METHOdOLOGY}

Research Design: This study was a survey and used quantitative analysis.

Population Sample: The population constituted 313 third year undergraduate students and forth year post graduate students of eleven departments of the four faculties of the University of Maroua. They were therefore well suited to evaluate the influence of professionalization of Higher Education in the University of Maroua.

Research Instruments: The questionnaire consisted of 7 questions constructed along the pattern of the Likert scale: Strongly agree (SA), Agree (A), Not sure (NS), strongly disagree (SDA), Disagree (DA). 
Assessing the Teaching/Learning Programs and the Professionalization of Higher Education in the University of Maroua, Far North Region of Cameroon

\section{Presentation and Analyses of Results}

\subsection{Research Hypothesis}

Ha: The availability of effective teaching/learning programs, effective teaching methods, qualification and teachers competence and the integration of theory and practice determines the level professionalization of higher education in the University of Maroua.

$\boldsymbol{H o}$ : The availability of effective teaching/learning programs, effective teaching methods, qualification and teachers', and competence and the integration of theory and practice do not determine the level professionalization of higher education in the University of Maroua.

Table1. Descriptive Statistics

\begin{tabular}{|c|c|c|c|c|c|c|c|c|c|}
\hline $\begin{array}{l}\text { Notions on } \\
\text { Professionalization } \\
\text { of; } \\
\text { Teaching/Learning } \\
\text { Programs, } \\
\text { Qualification and } \\
\text { Teachers } \\
\text { competence and } \\
\text { Learning } \\
\text { infrastructure }\end{array}$ & & SA & A & NS & DA & SDA & Mean & $\begin{array}{l}\text { Std. } \\
\text { Deviation }\end{array}$ & Total \\
\hline \multirow{2}{*}{$\begin{array}{l}\text { Professionalization } \\
\text { is reflected in the } \\
\text { teaching/learning } \\
\text { programs }\end{array}$} & Frequency & 14 & 60 & 70 & 86 & 83 & \multirow[b]{2}{*}{3.52} & \multirow[b]{2}{*}{1.198} & 313 \\
\hline & Percentage & 4.5 & 19.2 & 22.4 & 27.5 & 26.5 & & & 100 \\
\hline \multirow[b]{2}{*}{$\begin{array}{l}\text { There is effective } \\
\text { dissemination of } \\
\text { information on } \\
\text { competences } \\
\text { expected of each } \\
\text { degree program }\end{array}$} & Frequency & 15 & 54 & 44 & 75 & 125 & \multirow[b]{2}{*}{3.77} & \multirow[b]{2}{*}{1.27} & 313 \\
\hline & Percentage & 4.8 & 17.3 & 14.1 & 24.0 & 39.9 & & & 100 \\
\hline \multirow[b]{2}{*}{$\begin{array}{l}\text { Professionalization } \\
\text { of courses integrates } \\
\text { theory and practice } \\
\text { (internship } \\
\text { placement) }\end{array}$} & Frequency & 24 & 40 & 80 & 75 & 94 & \multirow[b]{2}{*}{3.55} & \multirow[b]{2}{*}{1.25} & 313 \\
\hline & Percentage & 7.7 & 12.8 & 25.6 & 24.0 & 30.0 & & & 100 \\
\hline \multirow{2}{*}{$\begin{array}{l}\text { My teachers are } \\
\text { highly qualified and } \\
\text { competent }\end{array}$} & Frequency & 46 & 57 & 60 & 70 & 80 & \multirow[b]{2}{*}{3.25} & \multirow[b]{2}{*}{1.29} & 313 \\
\hline & Percentage & 14.7 & 18.2 & 19.2 & 22.4 & 25.6 & & & 100 \\
\hline \multirow{2}{*}{$\begin{array}{l}\text { I am satisfied with } \\
\text { the teaching } \\
\text { methods used by my } \\
\text { teachers }\end{array}$} & Frequency & 33 & 60 & 60 & 70 & 90 & \multirow[b]{2}{*}{3.39} & \multirow[b]{2}{*}{1.35} & 313 \\
\hline & Percentage & 10.5 & 19.2 & 19.2 & 22.4 & 28.8 & & & 100 \\
\hline \multirow[b]{2}{*}{$\begin{array}{l}\text { Effectiveness of the } \\
\text { training as per the } \\
2008 \\
\text { University } \\
\text { Governance } \\
\text { Program to match } \\
\text { the "One Student- } \\
\text { One job" } \\
\text { Policy. }\end{array}$} & Frequency & 10 & 22 & 69 & 67 & 145 & \multirow[b]{2}{*}{4.00} & \multirow[b]{2}{*}{1.12} & 313 \\
\hline & Percentage & 3.2 & 7.0 & 22.0 & 21.4 & 46.3 & & & 100 \\
\hline \multirow{2}{*}{$\begin{array}{l}\text { I am satisfied with } \\
\text { the learning } \\
\text { infrastructure }\end{array}$} & Frequency & 18 & 32 & 43 & 91 & 129 & \multirow[t]{2}{*}{3.89} & \multirow[t]{2}{*}{1.21} & 313 \\
\hline & Percentage & 5.8 & 10.2 & 13.7 & 29.1 & 41.2 & & & 100 \\
\hline
\end{tabular}

\section{Inferential Statistics.}

\section{Multiple Regression Analysis.}


Assessing the Teaching/Learning Programs and the Professionalization of Higher Education in the University of Maroua, Far North Region of Cameroon

Table2. Model Summary

\begin{tabular}{|l|l|l|l|l|}
\hline Model & R & R Square & Adjusted R Square & Std. Error of the Estimate \\
\hline 1 & $.990^{\mathrm{a}}$ & .980 & .967 & .53863 \\
\hline
\end{tabular}

a. Predictors: (Professionalization of Higher Education), Teaching-learning programs, qualification and teacher competence, teaching methods, dissemination of information on competences of degree programs.

b. The model summary provides the R, R-square, and Adjusted R-square which are important statistics that can be used to determine how well the regression model fits the data inputted. This is explained as follows:

- $\quad \mathrm{R}(0,990)$ is the multiple correlation coefficients. It indicates a good level of prediction. It shows an extremely high correlation between Impact of teaching-learning programs and the professionalization of higher education.

- $\quad$-square or $\mathrm{R}^{2}(0,980)$, represents the coefficient of determination, and shows the portion of variance on the professionalization of higher education accounted for by the dynamics of teaching-learning programs. This explains the fact that $98,0 \%$ of variability on the professionalization of higher education is explained by the dynamics of teaching-learning programs, whereas the remaining $2.0 \%$ is explained by factors out of the model.

- Adjusted R-square shows the variable-fit in the model. In this light, a high R-adjusted value $(0,967)$ indicates a very good variable-fit of all sub variables (Teaching-learning programs, qualification and teacher competence, teaching methods, dissemination of information on competences of degree programs) in predicting the professionalization of higher education.

Table3. $A N O V A^{a}$

\begin{tabular}{|l|l|l|l|l|l|l|}
\hline \multicolumn{2}{|c|}{ Model } & Sum of Squares & Df & Mean Square & F & Sig. \\
\hline \multirow{4}{*}{1} & Regression & 4356.337 & 5 & 1089.084 & 3753.942 & $.000 \mathrm{~b}$ \\
\cline { 2 - 8 } & Residual & 89.356 & 308 & .290 & & \\
\cline { 2 - 7 } & Total & 4445.693 & 313 & & & \\
\hline
\end{tabular}

a. Dependent Variable: Professionalization of Higher Education.

b. Predictors: (Constant) Teaching-learning programs, qualification and teacher competence, teaching methods integration of theory and practice in training, dissemination of information on competences of degree programs.

The ANOVA demonstrates that the overall regression model is a good fit for the data. This table indicates that higher education curriculum statistically significantly predicts graduates' transition into the world of work. That is $\mathrm{F}(5,308)=3753.942, p<0,05$.

Table4. Coefficients

\begin{tabular}{|c|c|c|c|c|c|}
\hline \multirow[t]{2}{*}{ Model } & \multicolumn{2}{|c|}{ Unstandardized Coefficients } & Standardized Coefficients & \multirow[t]{2}{*}{$\mathrm{T}$} & \multirow[t]{2}{*}{ Sig. } \\
\hline & B & Std. Error & Beta & & \\
\hline (Constant) & -0.133 & 0.135 & & -.982 & .327 \\
\hline -Teaching-learning programs. & 0.644 & 0.100 & 0.204 & 6.423 & .000 \\
\hline $\begin{array}{l}\text {-Qualification and teacher } \\
\text { competence. }\end{array}$ & 0.839 & 0.085 & 0.282 & 9.927 & .000 \\
\hline -Teaching methods & 1.172 & 0.090 & 0.421 & 12.963 & .000 \\
\hline $\begin{array}{l}\text {-Dissemination of information } \\
\text { on competences of degree } \\
\text { programs. }\end{array}$ & 0.359 & 0.074 & 0.106 & 4.814 & .000 \\
\hline
\end{tabular}

a. Dependent variable: The professionalization of higher education.

From the B column, we can observe that Teaching-learning programs $(0,644)$, Qualification and teacher competence $(0,839)$, Teaching methods $(1,172)$, Dissemination of information on competences of degree programs $(0,359)$, statistically predicts the professionalization of higher education. Moreover, all four variables are statistically different from Zero in the $\mathbf{t}$ column, and demonstrates a high level of statistical significance at an error margin of 0,05 . This result can be written generally as: $F(5,308)=3753.942, p<0,05$., $R^{2}=0,980$. This means that graduates' transition into the world of work is highly explained by the mode of professionalization in the teaching/learning programs. 


\section{FINDINGS}

Based on these results, one observes that in terms of pedagogy (teaching/learning programs) a majority of respondents disagreed $(27.5 \%)$ and strongly disagreed $(26.5 \%)$. This is supported by a small standard deviation, and closed to the mean $(\mathrm{M}=3.52$, SD $=1.198)$, indicating that professionalization is insufficiently reflected in the teaching learning programs. This can be explained by the fact that student-centered teaching and the transmission of skills and competences which are the goals of professionalization in higher education is taking place in the University of Maroua but needs to be improved upon. This is same for teaching methods where majority of respondents disagreed $(24.5 \%)$ and strongly disagreed $(28.5 \%)$. This is reinforced by a small SD close to the mean $(\mathrm{M}=3.39, \mathrm{SD}=1,35)$ indicating that teaching methods need to inculcate skills and competences on the learners. In this light, (Hussain and Sultan, 2010) assert that HE aims at developing skills and competences among students to live in the 21 st Century. Therefore a university teacher should involve students in the learning process through activities aiming to inculcate academic and social skills among them.

The 2008 Bachelor-Masters-Doctorate (BMD), reform advocated for the restructuring of University programs to include skills and competences that will permit learners have an easy socio-professional insertion into the job market. The response on the question of effective dissemination of information on skills and competences expected of each degree program showed that the majority of respondents disagreed $(24.0 \%)$ and strongly disagreed (39.9\%). This concurs with a small SD, very close to the mean $(\mathrm{M}=3.77, \mathrm{SD}=1,27)$ meaning a lot has to be done in this domain. Despite efforts made to revise the existing teaching/learning programs, what seems to be updated does not carry the requisite skills and competences to enable students meet the needs and challenges of the employment market. This is blamed on the fact that the conceiving of most of the curricula is done without involving private sector operators and professionals of the economy. This calls for concern on the relevance of the curricula and the effectiveness of preparing students for the employment market. Students still have little opportunity to develop practical and technical competences, problem solving experience, or communication and organizational skills. They would become capable of interpreting knowledge according to situations, making their own meaning out of it. Li, (2001) affirms this by stating that critical thinking, problem-solving approaches and analytical skills are assumed to be the essential constructs of HE graduates. Equipped with such facilities and skills they construct new knowledge based on their own previous experiences and involvement in the learning process.

In a response to the Leitch review of skills (2006) in the U.K, the Department for Innovation, Universities and Skills asked in 2009 the Higher Education Funding Council to take forward work in this area. Three strands of work for the Funding Council were defined as crucial for higher education policy. First, in order to build the skilled, adaptable workforce that is needed for the future, an increase in the number of students is needed. A long term target has been set that by 2020 at least $40 \%$ of the working age population should have a higher level qualification (level four or above). Increases in the current grant for teaching would allow a significant expansion with a particular focus on the need to increase participation in HE by underrepresented groups from all parts of the working population, to support flexible and innovative delivery models, and to offer better local access to HE in places where there is a shortage of supplye. Second, to accelerate progress towards a new relationship between employers and higher education. This involves increasing volumes of employer co-funding being brought to bear to support skills development. This not only means a new approach to funding, but also a need for innovation and cultural change: providers will need a growing appreciation of the requirements in the workplace; to provide and adapt courses swiftly in response to demand; to offer provision tailored to individual business; and make it accessible in ways that suit employers and students ${ }^{\circ}$. Third, the need to widen participation, identifying and nurturing talent so that higher education is truly available to all who have the potential to benefit from. The Government has set a target to increase participation in HE towards 50 percent of those aged 18 to 30 .

The accession of Cameroon to the Bologna process is the increased use of the competence approach for the training of highly qualified professionals to meet the requirements of the modern labor market. Competence-oriented education is aimed at achieving planned ultimate goals of the education competences, that is reflected in the 2007 BMD Reform. The development of the competence approach is determined by the following factors: the emergence of a new type of economy 
determining the need for changes in requirements to the quality of graduates training, the content of labor and professional activities; rapid development of information technology; increasing priority of creative aspects of professional and intellectual capacity of specialists; dynamics growth of professions' modification. The introduction of competence approach has seriously affected all components of the learning process and requires substantial reconsideration of curriculum, teaching methods and traditional control - evaluation systems.

The curriculum theory is relevant in this context in addressing the preoccupation raised above. The objectives and aims of professionalizing education are to develop specific skills, competences and knowledge so that graduates can become employed using the skills they have learnt in productive ways in the labour market or creating employment for themselves. It is in this light that we think that the University of Maroua can meet the ever changing needs of the labour market and society by producing curricular that will lead to producing graduates who can easily transit to the world of work and maintain their employability while in the job market. The curricula of universities should possess packages of skills and competences in the learning programs as previewed by the BMD 2007 reform to enable graduates adapt to the needs national economy and employment market.

The curriculum theory in relation to this research paper is built on the ideals of (Anderson et al., 2016), who hold that curriculum should be built across the ideals of the society and to serve as an instrument for the reconstruction of the society. This is further reinforce by (Diamond,1998), who hold that curriculum should be conceived by taking into consideration the needs of the society in what he termed "Needs analysis" sufficiency of resources to succeed with a new programme, a feedback from the stakeholders of the existing curricula and building an educational philosophy on the rationale for the new programme. This forms a solid base for the professionalization of the teaching/learning programmes of the university.

The responses obtained from the integration of theory and practice in the programs of learning indicated that the bulk of respondents disagreed (24.0\%) and strongly disagree $(30.0 \%)$. This is supported by a small $\mathrm{SD}$ which is very close to the mean $(\mathrm{M}=3.35, \mathrm{SD}=1.25)$. This portrays a low rate of internship placement during training in the departments of the faculties. Classical university training has been accused of being too theoretical and doesn't march the needs of present day economy and job market. Based on the rational on technological view of knowledge, founded on the positivist notions, theoretical knowledge is viewed as a product, which is transferable from one context to another. Professional competence is based on research or science and disseminated via education and scientific knowledge is applied to specific definable problems in professional practice. However, (Eraut et al, 2000) argues that the learning context is central to the process through which codified knowledge is acquired. Using the codified knowledge in another context will require additional learning. The personal use of codified knowledge is related to its personal historical use, in one or a range of various contexts, and the integration with other knowledge.

While theoretical knowledge is associated with academia, practical knowledge is associated with practical experience (Abrandt, 1997). Practical knowledge is further divided into two; elementary knowledge and qualified practical knowledge. The elementary knowledge is associated strict and distinct rules and the ability to solve simple problems, routinized tasks in a stable and predictable context. Knowledge can be conveyed by means of information that covers most possible scenarios, by a central authority that alone is assumed to hold the knowledge and authority to interpret and innovate. Individual knowledge is associated with adapting to the rules. Qualified practical knowledge is related to distinct, vague and ambiguous rules that vary with the situation, and required independent thinking. Furthermore, qualified knowledge is associated with unpredictable and unstable contexts. The knowledge is conveyed by way of practical examples and general authority consists of individual coordination. Knowledge and authority to innovate and criticize are spread among the practitioners and rest on the professional values, (Abrandt, 1997).

The formal educational system is expected to convey knowledge applicable in work and prepares student for future work tasks. From the world of work, there are expectations that the formal educational system will produce potential employees who can contribute to organizational development and increased efficiency and the graduates expects to be able to apply the knowledge acquired through education in his or her future job. Different kinds of knowledge are valued in the 
educational system and the world of work. In working life, knowledge that is practically applicable is valued whereas the education system validates knowledge based on scientific criteria of correctness. However "the gap between education and work cannot be resolved only by making school knowledge more similar to everyday experience. The challenge lies in a dynamic interface between schoolknowledge, experience based knowledge and practical applications at work" (Abrahamsson, 1999; 141).

Furthermore, it has been argued that there is the lack of common understanding and language of skills between higher education institutions and employers. Part of the problem is the assumption that skills have the same meaning in the higher education context and in the employment context, which is not necessarily the case. The gap between the competence graduates acquired in higher education and the expectations of employers can partly be explained by language and cultural differences between educational system and work place which can lead to disparities between education and employers expectations. There are differences in the perceptions of what constitute generalist knowledge and the transferability of this knowledge. This lead to different perspectives on what the purpose of higher education should be and what the students should learn (Lombardy, 2002). This holds true with graduates of most Cameroonian universities who acquired skills and competences while at the work place quite different from the theoretical training in university. For example a graduate with a degree in Sociology may learn and acquire more skills while working for a Non-Governmental Organization dealing with welfare and rural children education.

However there seems to be consensus on whether there exist a gap between employers demand and the graduates' asset when they enter the work place, exactly what the gab consist of, how big it is or where and in what ways it constitute a problem (Atkins 1999). As Atkins (1999) pointed out, there is no reason as to why there should exist a common set of competencies that all employers need or demand as this could very well vary according to country, company, sector, organizational structure, region, size of business, type of business, and market orientation. In Cameroonian context, the Ministry of Higher Education is having consultations with GICAM (Association of Employers and Economic Operators in Cameroon) on ways of better understanding the needs and expectations of the private sector employers and how this can be integrated into the curricular of Cameroon's higher education system. The Stakeholder theory of (Freeman et al., 2004), can be relevant here as the involvement of companies and enterprises in the conception of degree programs can lead to a framework of social responsibility in universities based on the stakeholder theory. Thus introducing university initiatives aim at charting the professional progress of graduates, offering courses adapted to the needs of the society, educating students in terms of abilities and skills to ease employability chances, encouraging subjects related to social responsibility, business ethics and entrepreneurial culture.

Furthermore different generalist competence is likely to have a different impact in different professions. Thus, in what ways the universities should or even could change their curriculum is still very unclear. The type of institution and program (for example, applied programs versus more traditional) from which the students graduate is one of the factors that has an impact on the experiences of the transitional process from education to work (Teichler, 1998). The demands encountered by an engineer differ from the demands faced by a physician as to the structure and the organization of the educational programs. Thus the knowledge and attitudes the educational program is intended to give the graduates also differ between different educational programs.

Current trends of modern higher education in the world are characterized by its increasing practiceoriented character. This fact is explained by the desire of universities to prepare professionals being able to adapt, as soon as possible, to rapidly changing conditions of professional activities, new information technologies and communication systems, which have penetrated and become an integral part of any modern profession. Formation of competences, aimed at ensuring the future professional activity, requires only professionally directed knowledge and skills, that is in conflict with the need to develop the foundations of objective knowledge, basic concepts and phenomena, the study of the fundamental principles and laws, and forms a mosaic pattern of information among the students. This aspect defines an organization of the learning process, when cutting time of discipline requirement, it is necessary to include fundamental and applied data and knowledge unjustly derived from the content of the discipline (Ledneva, 1990). 
Assessing the Teaching/Learning Programs and the Professionalization of Higher Education in the University of Maroua, Far North Region of Cameroon

Professionalization, professional orientation, professional skills, professional activity, interdisciplinary skills are some of the key aspects of the 2007 BMD Reform in Cameroon's Higher Education system. However, fundamentalization of vocational training of a specialist in the logic of competence approach, the integration with the professionalization of training is not enough disclosed in modern research. This condition requires improving the methodology and strategy of selection and structuring of content, methods, organizational forms and means of education corresponding to tasks of mobile specialist training, who possesses a complex of professionally important qualities useful in modern conditions, (Makhmutov, 1985).Therefore targeting the learning process on the ability to apply the acquired knowledge in practice is typical for the competence approach. The purpose of the competence training is to develop not only knowledge and skills, but also such personal qualities (competences), which provide the ability and willingness to use the developed knowledge and skills in practical activities (competency).

The new university governance program of 2008 which provides for training to graduates to match the 'one-student-one-job' slogan was one of the key questions to determine the impact of professionalization on training programs. The effectiveness of the application of the 'One-StudentOne-Job' slogan for university graduates most of the respondents disagreed (21.4\%), and strongly disagreed $(46.3 \%)$. This is corroborated by a small $\mathrm{SD}$, very closed to the mean $(\mathrm{M}=4.00$, $\mathrm{SD}=1.12$ ). This implies that a lot still has to be done in terms of concrete action in the field. That is, transforming this slogan into practical reality by rendering training adaptable to the needs of the job market and also intensifying job placements internship in all the disciplines of training. Hence, one can conclude that the implementation of university governance policies has to a lesser extent influence the professionalization of higher education in Cameroon as much still remains to be done. A lot still has to be done in terms of rendering training more practical and relevant to the needs of the job market. The slogan of one student one job can be realized if there is concrete partnership between employers and professionals in conceiving the curricular and internships in job placing the graduates.

The new university governance program needs to provide adequate strategies for graduate employability and socio-professional insertion. The national economy, science and technological needs of the country should be reflected in the training programs of our higher institutions of learning. In fact, the knowledge and market base economy approach to higher education should be the focus. On the strength of the Stake Holder Theory by (Freeman et al., 2004), the need for professionalization in university education compels universities to interact with numerous and more varied stakeholders. Therefore, in order to assure their role in modern society, universities are obliged to completely reconsider their mission and vision as well as expectations and paying attention to stakeholder theory. The involvement of companies and enterprises in the conception of degree programs can lead to a framework of social responsibility in universities based on the stakeholder theory. Thus introducing university initiatives aim at charting the professional progress of graduates, offering courses adapted to the needs of the society, educating students in terms of abilities and skills to ease employability chances, encouraging subjects related to social responsibility, business ethics and entrepreneurial culture.

The response rate on learning infrastructure equally recorded the bulk of the sample that disagreed $(29.1 \%)$ and strongly disagreed $(41.2 \%)$. This is matched by a small SD, very close to the mean $(\mathrm{M}=3.89, \mathrm{SD}=1.21)$ signifying an insufficient state of infrastructure in the University of Maroua. Quality higher education is dependent on the quality and quantity of human and material resources put in place in institutions of higher learning. One of the goals of the BMD 2008 reform is advocating for a more professionalized system that facilitates the acquisition of practical skills and competencies for graduates to become more professionally adaptive and competitive in the labor market. However, with the lack of and insufficient infrastructure such as limited classroom space, science laboratories, internet, workshops and libraries to match the growing student population, the goal of professionalization becomes difficult to accomplish resulting to deteriorating of quality of education and learning.

The total development of the learners' in the cognitive, affective and psychomotor domains of learning can only take place in an environment that is conducive to teaching and learning. The provision of adequate and appropriate facilities is indispensable in the educational process. Olagboye (2004), viewed utilization of school infrastructure and learning environment as the extent of usage of 
school buildings, laboratories, libraries and so on. However, too much pressure on their use could result in over utilization, rapid deterioration and breakdown. For example, an amphi-theatre constructed to accommodate 250 students is constantly being used by 400 students, and then the returns from these facilities may not be maximized in terms of teaching and learning.

Adequate learning facilities will not only boost the professionalization process but will also ensure the realization of the goals of the BMD Reforms of 2007 and 2008 New University Governance Policy. All the above tie down to the fact that all public universities are run and managed by the State which is the sole resource provided. Resource dependence theory postulates that when there are several providers of resources, organizations may have choices and consequently they are less dependent on one resource provider in the environment. Universities could solicit from funding from other resource providers to build, improve and ameliorate on the state infrastructure in the university thereby avoiding to solely depend on state. Some of the obstacles to the implementation of the university governance program on the professionalization of higher education in the faculties of the University of Maroua are insufficient infrastructural and material resources to accompany the process.

\section{CONCLuSion}

Contemporary higher education now has a role to play in contributing to knowledge based economies which need to be driven by highly skilled, competent and flexible individuals. Cameroon's higher education is one of the leading strategic sectors of development as seen in her current development document, the Growth and Employment Strategy Paper (GESP) of 2009. The main driving force for change is increased demand for more professionalization of Higher Education programs to suit the exigencies of the Job Market, more accountability and responsiveness to the needs and expectations of internal and external stakeholders who affect or are affected by the existence and functioning of universities.

Professionalization policies on the teaching/learning programs (pedagogy), integration of theory and practice in training (internship placement), and learning infrastructure, do not adequately reflect professionalization in the University of Maroua. The results of the tested hypotheses and the examination of additional findings led to certain conclusions. The overall picture that emerged from the survey show that to some extent there is a relationship between Professionalization policies on the teaching/learning programs (pedagogy), integration of theory and practice in training (internship placement), and learning infrastructure in the University of Maroua. Hence, a curriculum reform is strongly recommended to assume a systemic approach to enhance the Professionalization of the Teaching/Learning process through;

1. Connection between learning programmes and the world of work

2. Interdisciplinary connection in training programmes

3. Construction of discipline's work program with expected skills and competences

4. Internship placement of students

5. Availability of pedagogic tools for the implementation of the professionalization of subject content

6. Availability Resource Inputs (Infrastructure, Personnel and Equipment) to facilitate the professionalization process

Finally, the picture of the journey towards governance policies on professionalization can only be gotten and appreciated through a regular monitoring of the teaching/learning process, using a bottomup approach (Department-Faculty-Administration). This will enable the university in prioritizing its needs. Without a monitoring mechanism, the effort of the university towards professionalization may not be relevant. Also, educational planners and policy makers need to constantly monitor the strategies put in place to achieve professionalization in the university. This will permit them assess the difficulties hindering the professionalization process in the university and hence adopt new strategies. Changes were made in the administrative part of the BMD 2007 reform, but a lot still has to be done in the pedagogic aspect because the importance of pedagogy in achieving learning outcomes cannot be overemphasized 
Assessing the Teaching/Learning Programs and the Professionalization of Higher Education in the University of Maroua, Far North Region of Cameroon

\section{RECOMMENDATIONS}

As Higher Education in Cameroon continues its transition toward more market-oriented features, we recommend several steps to help in accelerating the professionalization process in our Higher Education. Findings of the study show that the 2007 BMD reform and 2008 New University Governance Policy which had as one of each the quest for the professionalization of teaching/learning process in the University, had two lapses. The reforms on the professionalization of programs in the university are not accompanied with sufficient resources that can permit a realistic realization of the goals of the reforms. Secondly, there is no adequate follow-up from the Ministry of Higher Education to actually see what is going on in the university so as to evaluate and see the difficulties that are inherent in the process, so as to be able to come out with meaningful solutions to ameliorate on the process to attain quality professionalization in the university.

The theory of planning to succeed should therefore draw a link between preparation-adoption and execution of policies. The Department in charge of Planning and Professionalization of teaching in the Ministry of Higher Education should do regular missions in the field to assess and evaluate the progress and difficulties inherent in the professionalization process. We cannot talk of One StudentOne - Job if the student is not truly trained for an employment. For students to be truly trained for a job there must be concrete interaction between the world of enterprise (public and private) and the University world. It is also pertinent that in every faculty there should be a unit with a precise role to handle the interaction with the world of enterprise. This interaction could be internship research, follow-up internship of students with enterprises and prepared convections and signing of corporation accords.

In the continuous effort to render higher education curricula relevant to the socio-economic needs of the nation, higher education authorities need to continuously develop and provide a balanced curricula that is relevant, responsive, culturally sensitive and adequately supported by appropriate teaching and learning materials. A major challenge to our curriculum is that of science and technology. Science and technology should be reform with special focus on the use of ICTs. Teaching methods should encourage linkages between science and technology on one hand and with the learner's culture and environment on the other. Essential life skills should be systematically infused into the curricula. Important areas such as inter-personal skills, critical thinking, communication, entrepreneurship education, self-directed learning, civic/leadership-skills education, preventive health education etc are imperative for the $21^{\text {st }}$ century knowledge economy. The infusion process should pay attention to African knowledge systems.

For professionalization to be attained in the teaching/learning process in the university there must be adequate networking, cooperation and partnerships between the university and industry. Findings from the study show there is little partnership between the university of Maroua and enterprises and industries to enhance students placements for internship. University administrators should intensify and allocate time for internships in all the departments. These offer students the opportunity to develop critical thinking, analytical and professional skills needed for the workplace that lecturers may not be able to impart. In preparing for a successful career, one of the most important steps is securing and completing an internship before graduation. It helps students gain real-world experience and offers them an educational enrichment as they apply knowledge and skills gained in class.

Internships or practicals are good examples of a constructivist approach to teaching. Internships are the link between the theoretical knowledge and concepts learned in classroom setting, and real time industry applications. Thus, university administrators should consider internships as an important component in preparing undergraduate students for the entry-level job market. It can also provide students with valuable opportunities for growth through the shadowing of mentors, attendance of meetings, and actual performance of duties. Students participating in internships could also have a significant effect on career preparation over students without such experiences in five skill areas: computer applications, creative thinking, job interviewing, networking, and relationship building, (Radigan, 2009). Authorities of the University of Maroua should strengthen cooperation through partnerships which can benefit students from the above advantages which are very vital in achieving professionalization. Without professionalization in university education will be far from being attained. 
Assessing the Teaching/Learning Programs and the Professionalization of Higher Education in the University of Maroua, Far North Region of Cameroon

\section{REFERENCES}

[1] Abrahamson, K. (1999). Bridging the Gab between Education and Work. In: Van Weieringen F. \& Attwell G. vocational and Education in Europe. Dordercht: kluwer Academic publishers.

[2] Abrandt, M. (1997). Learning Physiotherapy: The Impact of Formal Education and Professional Experience. Linköping studies in Education and Psychology. $\mathrm{N}^{\circ} .50$. Linkoping: Linköping University.

[3] Anderson, E., Smith, R., \& Hammick, M. (2016). Evaluating an interprofessional education curriculum: a theory-informed approach. Medical teacher, 38(4), 385-394.

[4] Atkins M.J. (1999). Oven-ready and self-basting: taking stock of employability skills. Teaching in higher education 4 (2): 267-278.

[5] Bloom, D.E, \&Rosovsky. (2006). Beyond private gain. The public benefits of Higher Education. In J.F James \& Philip G. Altbach (Eds). International hand book of higher education. Boston.

[6] Burrows, J. (1999).Going beyond labels: A Framework for profiling institutional stakeholders. Contemporary Education. 70(4), 5-10.

[7] Clark, B., (1998). Entrepreneurial universities: Organizational pathways of transition. Paris: international Association of universities.

[8] Diamond, R.M. (1998) Designing and Assessing Courses and Curricula: A Practical Guide. San Fransisco: Jossey-Bass.

[9] Dill, D. (2000).Capacity building as an instrument of institutional reform. Improving the quality of higher education through academic audits in The UK. Journal of Comparative policy Analysis: Research and Practice, 2, 211-234

[10] Earthman, G. I. (2002). School facility conditions and student academic achievement. https://escholarship. org/content/qt5sw56439/qt5sw56439.pdf. Retrieved on 01/16/2021.

[11] Eraut, M. (1994). Developing professional knowledge and competence. King's Lynn: the Falmers Press.

[12] Freeman, R. E., Wicks, A. C., \& Parmar, B. (2004). Stakeholder theory and "the corporate objective revisited". Organization science, 15(3), 364-369.

[13] Gerber, L. (2001). Inextricably linked; Shared governance and academic freedom. Academe, 87(3), 22-24.

[14] GESP. (2009). Growth and Employment Strategy Paper: Government reference framework action for 2010-2020.

[15] Gibbons, M., Limoges, C., Nowotny, H., Schwartzman, S., Scott, P., \&Trow, M. (1994). The new production of knowledge: The dynamics of science and research in contemporary societies. Sage.

[16] Government of Cameroon. (2006). Poverty reduction strategy paper. Third annual progress report, IMF, Washington D.C.

[17] Hussain, I., and Sultan, S. (2010). Learning by doing: Outcomes of teaching, a research course through group activities. Proceedings of the annual international conference on computer sciences education innovation and technology (CSEIT). Singapore: Global Sciences and Technology Forum, 6-7 December, 2010

[18] Ledneva, O. V. (1990). Social problems of formation of a professional orientation of the person. PhD Thesis, Saratov, 180.

[19] Leitch, S. (2006). Prosperity for all in the global economy-world class skills. The Stationery Office. https://books.google.cm/books?. Retrieved on 01/16/2021.

[20] Li, W. (2001). Constructivists learning systems: A new paradigm. International conference on advanced learning techniques. Madison; 6-8 August 2001

[21] Lombardi, J.V., Craig D.D., Capaldi E.D., \&Gater, D. S. (2002). University organization, Governance and competiveness: The Lombardi program on measuring University Performance. Grainsville, FL: The center, university of Florida.

[22] Machin, S \& McNally, S. (2007) Tertiary Education Systems and Labour Markets, A paper commissioned by the Education and Training Policy Division, OECD for the Thematic Review of Tertiary Education

[23] Makhmutov, M. I. (1985). Modern lesson. Pedagogy. https://scholar.google.com/scholar?hl=fr\&as_ $\mathrm{sdt}=0 \% 2 \mathrm{C} 5 \& \mathrm{q}=+$ Makhmutov\%2C+M.+I.+\%281985\%29.+Modern+lesson.+Pedagogy.\&btnG=. Retrieved on $01 / 16 / 2021$.

[24] Marginson, S., \& Van Der Wende, M. (2007). Globalization and Higher education. Paris: OECD/CERI.

[25] Nayyar, D. (2008) 'Globalization: What Does it Mean for Higher Education'. In Weber, L.E. and Duderstadt, J.J. (ed.) The Globalization of Higher Education. London: Economica Ltd

[26] Olagboye, A.A., (2004). Introduction to educational Planning and Supervision. Ikeja: Jaja Educational Research and Publishers Ltd. 
Assessing the Teaching/Learning Programs and the Professionalization of Higher Education in the University of Maroua, Far North Region of Cameroon

[27] Radigan, J. (2009). The role of internships in higher education. Retrieved on 11th April 2014, from www.asee.org/documents/sections/middle-atlantic/fall-2009/01.

[28] Teichler, U. (1998). The transition from higher education to employment in Europe. Higher Education in Europe 23 (4): 535-557.

Citation: Dr.Asongwe Cyprian Foche. "Assessing the Teaching/Learning Programs and the Professionalization of Higher Education in the University of Maroua, Far North Region of Cameroon" International Journal of Humanities Social Sciences and Education (IJHSSE), vol 8, no. 2, 2021, pp. 35-47. doi: https://doi.org/10.20431/2349-0381.0802005.

Copyright: () 2021 Authors. This is an open-access article distributed under the terms of the Creative Commons Attribution License, which permits unrestricted use, distribution, and reproduction in any medium, provided the original author and source are credited. 